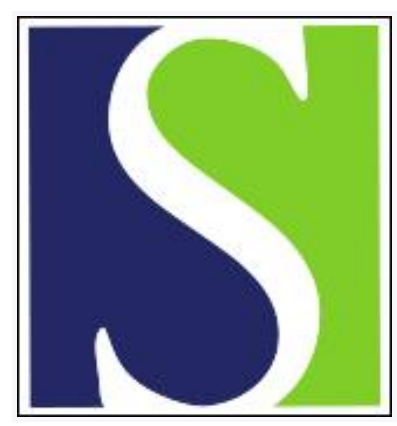

Scand J Work Environ Health 1995;21(2):106-115

https://doi.org/10.5271/sjweh.17

Issue date: Apr 1995

Mortality and cancer incidence among Swedish fishermen with a high dietary intake of persistent organochlorine compounds by Svensson B-G, Mikoczy Z, Strömberg U, Hagmar L

The following article refers to this text: 2002;28(2):124-132

Key terms: cancer incidence; dietary intake; fish consumption; fisherman; IHD; ischemic heart disease; mortality; multiple myeloma; n-3 polyunsaturated fatty acid; PCP; persistent organochlorine compound; polychlorinated biphenyl; polychlorinated dibenzo-p-dioxin; polychlorinated dibenzofuran; selenium; squamous-cell skin cancer; stomach neoplasms; Sweden

This article in PubMed: www.ncbi.nlm.nih.gov/pubmed/7618056 


\title{
Mortality and cancer incidence among Swedish fishermen with a high dietary intake of persistent organochlorine compounds
}

\author{
by Bengt-Göran Svensson, MD,' Zoli Mikoczy, BSc,' Ulf Strömberg, PhD, ' Lars Hagmar, MD'1
}

\begin{abstract}
Svensson B-G, Mikoczy Z, Strömberg U, Hagmar L. Mortality and cancer incidence among Swedish fishermen with a high dietary intake of persistent organochlorine compounds. Scand $J$ Work Environ Health 1995:21: $106-15$.
\end{abstract}

\begin{abstract}
Objectives The objective of this study was to determine mortality and cancer incidence in two cohorts of Swedish fishermen with different dietary intakes of persistent organochlorine compounds.

Methods The following two cohorts of Swedish fishermen were established: a cohort of 2896 subjects from the Swedish east coast (on the Baltic Sea), and a cohort of 8477 subjects from the Swedish west coast. Mortality and cancer incidence were studied in these cohorts and comparisons were made both with the regional populations and between the cohorts.

Results The incidences of stomach and squamous cell skin cancers among the eastcoast fishermen were elevated as compared with those of the regional population [standardized incidence ratio (SIR) 1.6, 95\% confidence interval (95\% CI) $1.0-2.4$ and SIR 2.3, 95\% CI 1.5-3.5 respectively] and with the westcoast cohort (IRR 2.2, 95\% CI 1.3-3.5 and IRR 1.9, 95\% CI 1.2-3.1, respectively), while that of colon cancer was decreased. Moreover, mortality from multiple myelomas was increased among the eastcoast fishermen as compared with that of the general population [standardized mortality ratio (SMR) 3.1,95\% CI 1.2-6.4) and the westcoast fishermen (IRR 3.2, 95\% CI 1.2-8.7). A 12\% decreased mortality in ischemic heart disease was found for the eastcoast cohort. A slight, but significant increase in such deaths was noted among the westcoast fishermen.

Conclusions High consumers of fatty fish, contaminated with organochlorine compounds, had an increased risk for stomach and skin cancer. They also had a suggestive decrease in mortality from ischemic heart diseases.

Key terms fish consumption, ischemic heart disease, multiple myeloma, n-3 polyunsaturated fatty acids, polychlorinated biphenyls, polychlorinated dibenzo p-dioxins and furans, selenium, squamous cell skin cancer, stomach neoplasms.
\end{abstract}

Swedish fishermen eat more than twice as much fish as the general population of Sweden (1). Fishermen from the west coast of Sweden preferably eat lean fish (cod and flat fish), in contrast to the fishermen from the east coast (Baltic Sea), who have a much higher intake of locally caught fatty fish (salmon and herring). As fatty fish from the Baltic Sea contain rather high levels of carcinogenic persistent organochlorine compounds, for example, polychlorinated biphenyls (PCB) (2), polychlorinated dibenzo-p-dioxins (PCDD), and polychlorinated dibenzofurans (PCDF) (3), there is some health concern about a high dietary intake of such fish. The dietary habits of the fishermen were reflected by two times higher total toxic equivalents of $\mathrm{PCB}$ and $\mathrm{PCDD} / \mathrm{PCDF}$ in plasma in eastcoast fishermen, compared with the equivalents of both westcoast fishermen and referents from each geographic area (1). In contrast, the blood levels of methylmercury did not differ between the people from the different coasts.

As the fishermen from the east and west coasts were similar socioeconomically, a comparison of cancer incidence was considered useful to assess the health effects of a high consumption of fatty fish from the Baltic Sea, contaminated with persistent organochlorine compounds. Another objective was to assess whether a high fish intake, especially of fatty fish species rich in n-3 polyunsaturated fatty acids (PUFA), was associated with a decreased risk for ischemic heart disease, as indicated previously (4).

Reprint requests to: Dr B-G Svensson, Department of Occupational and Environmental Medicine, University Hospital, S-221 85 Lund, Sweden. 


\section{Subjects and methods}

\section{Cohorts}

From the fishermen's organization covering the west coast of Sweden (Kattegatt and Skagerrak) records of names, dates of birth, addresses, and dates of start and end of membership were collected for 8493 (16 women) fishermen who had been members of the organization for one year or more. A 10-digit personal identification code could, however, not be retrieved for 16 subjects, who therefore were not included in the cohort. Corresponding information was obtained for 2907 (24 women) fishermen from the fishermen's organization covering the east coast (Baltic Sea). Eleven subjects were not fully identified and were therefore not included. The eastcoast cohort members lived along the south of the Baltic $(\mathrm{N}=1359)$, along the Baltic proper $(\mathrm{N}=1095)$, and along the Sea of Bothnia ( $\mathrm{N}=442)$.

The 1359 fishermen from the south of the Baltic Sea have previously been studied (5). The observation period for this part of the cohort was extended for another calendar year.

The westcoast fishermen had become members during the period 1930-1988 (median year of entry 1957). The records did not however, include any members who had let their membership expire or who had died before 1965. The corresponding entry period into the cohort was 1935-1988 (median year of entry 1970) for the fishermen from the east coast. All of the subjects who had let their membership expire or who had died were included in the register from 1968.

The fishermen from the west coast were older (median year of birth $1923 ; 25$ th percentile 1908,75 th percentile 1942) than those from the east coast (median year of birth 1939; 25 th percentile 1921,75 th percentile 1951).

Dietary habits had previously been studied in groups of the cohorts (1). Food frequencies for different food items, as well as coffee, tobacco, and alcohol consumption, had been investigated. Blood and urine levels of some xenobiotics were also studied for these subjects.

\section{Follow-up}

Vital status was determined as of 31 December 1988 (table 1) for all of the subjects in the cohorts. None of the subjects was lost to follow-up. The studied cohorts thus consisted of 8477 and 2896 subjects, respectively. Table 2 shows the distribution of person-years by age group and calendar year.

\section{Information on causes of death and tumors}

Information on causes of death for the period 1968 1988 for the eastcoast cohort and 1965-1988 for the westcoast cohort was obtained from Statistics Sweden. The death certificates were coded by Statistics Sweden according to the International Classification of Diseases (ICD). All codes were transformed to the 8 th revision of the ICD.

Information on tumors (coded according to the ICD, 7th revision), diagnosed from 1968 to 1988 in the eastcoast cohort and from 1965 to 1988 in the westcoast cohort, was obtained from the Swedish Cancer Register.

\section{Risk estimates}

Expected mortality for the periods 1968-1988 and 1965-1988 was calculated with calendar year, cause, gender, and specific death rates for five-year age groups for each county. These rates were calculated from death and population counts obtained from Statistics Sweden. The date of death or emigration was used as the individual end points, whichever occurred first.

Similarly, yearly morbidity rates for cancer were obtained from the Swedish Cancer Register. Date of death, tumor diagnosis, or emigration, whichever occurred first, was used as the individual end point.

\section{Statistical methods}

The $95 \%$ confidence intervals $(95 \% \mathrm{CI})$ for cause-specific standardized mortality ratios (SMR) or standardized

Table 1. Vital status as of 31 December 1988 for Swedish fishermen from the west and east coasts.

\begin{tabular}{lrrrrr}
\hline Vital status & \multicolumn{2}{c}{ West coast } & & \multicolumn{2}{c}{ East coast } \\
\cline { 2 - 3 } \cline { 5 - 6 } & \multicolumn{1}{c}{$N$} & $\%$ & & $\mathrm{~N}$ & $\%$ \\
\hline Living & 5655 & 66.6 & & 2471 & 85.0 \\
Dead & 2781 & 32.7 & & 421 & 14.5 \\
Emigrated & 41 & 0.5 & & 4 & 0.1 \\
\hline Total & 8477 & 100 & & 2896 & 100 \\
\hline
\end{tabular}

Table 2. Person-years under observation in the two cohorts of Swedish fishermen.

\begin{tabular}{lrrrr}
\hline Calendar-year & \multicolumn{4}{c}{ Age (years) } \\
\cline { 2 - 5 } & $<30$ & $30-59$ & $\geq 60$ & Total \\
\hline Westcoast fishermen & & & & \\
1965-1975 & 12978 & 36540 & 22746 & 72264 \\
1976-1980 & 3551 & 16650 & 11528 & 31729 \\
1981-1988 & 3839 & 24546 & 18929 & 47314 \\
$\quad$ Total & 20368 & 77736 & 53202 & 151307 \\
Eastcoast fishermen & & & & \\
1968-1975 & 2025 & 7047 & 2541 & 11613 \\
1976-1980 & 1541 & 5197 & 2362 & 9100 \\
1981-1988 & 3003 & 10453 & 5049 & 18505 \\
Total & 6569 & 22697 & 9952 & 39218 \\
\hline
\end{tabular}


incidence ratios (SIR) were calculated according to the Poisson distribution, or to the chi-square distribution if the expected values were greater than 10 . The term "significant" implies that the $95 \%$ confidence interval for the standardized mortality ratio or standardized incidence ratio does not include 1.00. All of the tests were twotailed.

Direct comparisons of mortality and cancer incidence between the east- and westcoast fishermen [incidence rate ratio (IRR)] were obtained from calculations of Mantel-Haenszel summary rate ratios for appropriate age- and calendar-year strata (6).

\section{Results}

\section{Mortality for the eastcoast fishermen}

A significantly decreased overall mortality was observed for the eastcoast fishermen (SMR 0.86, 95\% CI 0.78 0.95 ) (table 3). The mortality from cardiovascular diseases was also decreased (SMR 0.88, 95\% CI $0.77-$ $0.99)$. The observed number of deaths from ischemic heart disease was lower than expected (158 versus 180 , values giving the same SMR of 0.88 as for cardiovas- cular diseases, but fewer observations caused a somewhat wider $95 \%$ CI of $0.75-1.03$ ). In contrast to ischemic heart disease, the mortality from cerebrovascular diseases was not decreased. Deaths from malignant tumors were fewer than expected (SMR $0.84,95 \% \mathrm{Cl}$ $0.68-1.03$ ). Considering specific tumors, deaths from multiple myeloma were significantly increased (SMR $3.08,95 \%$ CI 1.24-6.35). Seventeen deaths due to stomach cancer (SMR 1.37, 95\% CI 0.82-2.23) were found. The eastcoast fishermen had also died more frequently by drowning (SMR 11.8, 95\% CI 6.29-20.2), and drowning was the main reason for the observed increase in deaths from violent causes (SMR 1.50, 95\% CI 1.15-1.96). There was no increase in alcohol-related deaths (SMR 0.73, 95\% CI 0.31-1.43).

\section{Mortality for the westcoast fishermen}

A significant decreased overall mortality was observed (SMR 0.93, 95\% CI 0.90—0.97) (table 4). Nevertheless, the observed number of deaths from cardiovascular diseases was similar to that expected (SMR 1.00). A slight, but significant, excess of deaths from ischemic heart disease was noted (SMR 1.06, 95\% CI 1.00-1.12). There was no increase in deaths from malignant tumors

Table 3. Mortality by detailed cause in 1968-1988 among 2896 fishermen from the east coast.

\begin{tabular}{|c|c|c|c|c|}
\hline Cause of deatha & $\begin{array}{l}\text { Observed } \\
\text { deaths } \\
\text { (N) }\end{array}$ & $\begin{array}{l}\text { Expected } \\
\text { deaths } \\
(\mathrm{N})\end{array}$ & $\begin{array}{l}\text { Standardized } \\
\text { mortality } \\
\text { ratio }\end{array}$ & $\begin{array}{l}95 \% \\
\text { confidence } \\
\text { interval }\end{array}$ \\
\hline All malignant neoplasms (140-209) & 90 & 107.4 & 0.84 & $0.68-1.03$ \\
\hline Alimentary organs $(150-159)$ & 31 & 40.9 & 0.76 & $0.52-1.08$ \\
\hline $\begin{array}{l}\text { Esophagus (150) } \\
\text { Stomach (151) } \\
\text { Colon }(153) \\
\text { Rectum }(154) \\
\text { Liver (155) } \\
\text { Pancreas (157) }\end{array}$ & $\begin{array}{r}2 \\
17 \\
1 \\
4 \\
1 \\
5\end{array}$ & $\begin{array}{r}2.1 \\
12.4 \\
8.1 \\
5.5 \\
2.1 \\
7.5\end{array}$ & $\begin{array}{l}0.97 \\
1.37 \\
0.12 \\
0.73 \\
0.48 \\
0.66\end{array}$ & $\begin{array}{l}0.12-3.49 \\
0.82-2.23 \\
0.00-0.69 \\
0.20-1.86 \\
0.01-2.65 \\
0.22-1.55\end{array}$ \\
\hline $\begin{array}{l}\text { Lung, larynx }(162-163) \\
\text { Melanoma }(172) \\
\text { Skin cancer }(173) \\
\text { Breast }(174) \\
\text { Prostata }(185) \\
\text { Bladder }(188) \\
\text { Kidney (189) } \\
\text { Brain, nervous system }(191-192) \\
\text { Hodgkin's lymphoma }(201) \\
\text { Non-Hodgkin's lymphoma }(200,202) \\
\text { Multiple myeloma }(203) \\
\text { Leukemia (204-207) }\end{array}$ & $\begin{array}{r}16 \\
0 \\
0 \\
1 \\
12 \\
5 \\
5 \\
2 \\
0 \\
3 \\
7 \\
5\end{array}$ & $\begin{array}{r}20.6 \\
2.1 \\
0.2 \\
0.2 \\
11.6 \\
3.8 \\
4.9 \\
3.4 \\
0.7 \\
2.5 \\
2.3 \\
3.6\end{array}$ & $\begin{array}{l}0.78 \\
0.00 \\
0.00 \\
4.17 \\
1.03 \\
1.31 \\
1.02 \\
0.59 \\
0.00 \\
1.20 \\
3.08 \\
1.38\end{array}$ & $\begin{array}{l}0.46-1.28 \\
0.00-1.73 \\
0.00-15.4 \\
0.10-23.2 \\
0.53-1.80 \\
0.42-3.05 \\
0.33-2.34 \\
0.07-2.13 \\
0.00-5.59 \\
0.25-3.49 \\
1.24-6.35 \\
0.45-3.22\end{array}$ \\
\hline Cardiovascular diseases (390-458) & 224 & 255.7 & 0.88 & $0.77-0.99$ \\
\hline $\begin{array}{l}\text { Ischemic heart diseases }(410-414) \\
\text { Cerebrovascular diseases }(430-438) \\
\text { Bronchitis, emphysema }(490-493)\end{array}$ & $\begin{array}{r}158 \\
41 \\
4\end{array}$ & $\begin{array}{r}180.0 \\
40.8 \\
8.9\end{array}$ & $\begin{array}{l}0.88 \\
1.00 \\
0.45\end{array}$ & $\begin{array}{l}0.75-1.03 \\
0.73-1.37 \\
0.12-1.15\end{array}$ \\
\hline Accidents, poisoning, violence $(800-999)$ & 58 & 38.5 & 1.50 & $1.15-1.96$ \\
\hline Drowning $(910)$ & 13 & 1.1 & 11.82 & $6.29-20.2$ \\
\hline Alcohol-related deaths $(291,303,571,577,860)$ & 8 & 11.0 & 0.73 & $0.31-1.43$ \\
\hline All causes $(000-999)$ & 419 & 484.5 & 0.86 & $0.78-0.95$ \\
\hline
\end{tabular}

a Code of the International Classification of Diseases (eighth revision) in parentheses. 
Table 4. Mortality by detailed cause in 1965-1988 among 8477 fishermen from the west coast.

\begin{tabular}{|c|c|c|c|c|}
\hline Cause of death ${ }^{a}$ & $\begin{array}{l}\text { Observed } \\
\text { deaths } \\
\text { (N) }\end{array}$ & $\begin{array}{l}\text { Expected } \\
\text { deaths } \\
\text { (N) }\end{array}$ & $\begin{array}{l}\text { Standardized } \\
\text { mortality } \\
\text { ratio }\end{array}$ & $\begin{array}{l}95 \% \\
\text { confidence } \\
\text { interval }\end{array}$ \\
\hline All malignant neoplasms $(140-209)$ & 594 & 612.4 & 0.97 & $0.89-1.05$ \\
\hline Alimentary organs (150-159) & 219 & 233.8 & 0.94 & $0.82-1.07$ \\
\hline $\begin{array}{l}\text { Esophagus (150) } \\
\text { Stomach }(151) \\
\text { Colon }(153) \\
\text { Rectum }(154) \\
\text { Liver }(155) \\
\text { Pancreas (157) }\end{array}$ & $\begin{array}{r}4 \\
63 \\
58 \\
31 \\
9 \\
33\end{array}$ & $\begin{array}{l}12.8 \\
68.0 \\
56.3 \\
30.5 \\
10.0 \\
39.5\end{array}$ & $\begin{array}{l}0.31 \\
0.93 \\
1.03 \\
1.02 \\
0.90 \\
0.84\end{array}$ & $\begin{array}{l}0.09-0.80 \\
0.72-1.19 \\
0.79-1.34 \\
0.70-1.46 \\
0.41-1.70 \\
0.58-1.18\end{array}$ \\
\hline $\begin{array}{l}\text { Lung, larynx (162-163) } \\
\text { Melanoma (172) } \\
\text { Skin cancer (173) } \\
\text { Breast (174) } \\
\text { Prostata (185) } \\
\text { Bladder (188) } \\
\text { Kidney (189) } \\
\text { Brain, nervous system (191-192) } \\
\text { Hodgkin's lymphoma (201) } \\
\text { Non-Hodgkin's lymphoma (200, 202) } \\
\text { Multiple myeloma (203) } \\
\text { Leukemia (204-207) }\end{array}$ & $\begin{array}{r}77 \\
6 \\
5 \\
3 \\
123 \\
20 \\
16 \\
15 \\
3 \\
14 \\
16 \\
24\end{array}$ & $\begin{array}{r}90.0 \\
8.9 \\
1.6 \\
1.3 \\
110.6 \\
19.9 \\
22.9 \\
14.3 \\
3.2 \\
15.7 \\
12.8 \\
24.6\end{array}$ & $\begin{array}{l}0.86 \\
0.67 \\
3.05 \\
2.36 \\
1.11 \\
1.00 \\
0.70 \\
1.05 \\
0.95 \\
0.89 \\
1.25 \\
0.97\end{array}$ & $\begin{array}{l}0.68-1.07 \\
0.25-1.46 \\
0.99-7.13 \\
0.49-6.88 \\
0.93-1.33 \\
0.62-1.57 \\
0.41-1.16 \\
0.59-1.73 \\
0.20-2.78 \\
0.49-1.49 \\
0.73-2.07 \\
0.63-1.47\end{array}$ \\
\hline Cardiovascular diseases $(390-458)$ & 1592 & 1595.2 & 1.00 & $0.95-1.05$ \\
\hline $\begin{array}{l}\text { Ischemic heart diseases }(410-414) \\
\text { Cerebrovascular diseases }(430-438) \\
\text { Bronchitis, emphysema }(490-493)\end{array}$ & $\begin{array}{r}1094 \\
257 \\
43\end{array}$ & $\begin{array}{r}1032.3 \\
285.8 \\
53.6\end{array}$ & $\begin{array}{l}1.06 \\
0.90 \\
0.80\end{array}$ & $\begin{array}{l}1.00-1.12 \\
0.79-1.02 \\
0.59-1.09\end{array}$ \\
\hline Accidents, poisoning, violence $(800-999)$ & 190 & 167.4 & 1.13 & $0.98-1.31$ \\
\hline Drowning $(910)$ & 15 & 7.1 & 2.11 & $1.18-3.48$ \\
\hline Alcohol-related deaths $(291,303,571,577,860)$ & 41 & 44.5 & 0.92 & $0.67-1.26$ \\
\hline All causes $(000-999)$ & 2781 & 2979.6 & 0.93 & $0.90-0.97$ \\
\hline
\end{tabular}

a Code of the International Classification of Diseases (eighth revision) in parentheses.

(SMR 0.97, 95\% CI 0.89-1.05). Considering specific tumors, the risk for death from cancer of the esophagus was significantly decreased (SMR $0.31,95 \%$ CI $0.09-$ $0.80)$. No specific tumor acting as a cause of death was significantly increased. Sixty-three deaths due to stomach cancer (SMR 0.93, 95\% CI 0.72-1.19) and 16 due to myeloma (SMR 1.25, 95\% CI 0.73-2.07) were found. As expected, the fishermen had died more frequently from drowning (SMR 2.11, 95\% CI 1.18-3.48). Deaths from other violent causes were not elevated, neither were deaths from alcohol-related diseases (SMR 0.92, 95\% CI $0.67-1.26)$.

\section{Cancer incidence for the eastcoast fishermen}

A total of 197 cases of cancer were observed among the eastcoast fishermen versus 193 expected (SIR 1.02, 95\% CI 0.88- 1.17) (table 5). The incidences of lip cancer and squamous cell cancer of the skin were significantly increased (SIR 2.60, 95\% CI 1.05-5.36 and SIR 2.28, $95 \%$ CI $1.45-3.50$, respectively). In contrast, no malignant melanomas were observed, in spite of five expected. There was also a significant increase in the incidence of stomach cancer (SIR 1.59, 95\% CI 1.03-2.39). On the other hand, colon cancers were significantly fewer than expected (SIR 0.37, 95\% CI 0.12-0.87). The suggestive increases of myelomas (SIR 2.08, 95\% CI 0.76-4.53) and acute leukemias (SMR 2.28, 95\% CI 0.74-5.33) were, however, not significant.

\section{Cancer incidence for the westcoast fishermen}

Altogether 979 cases of cancer were observed (SIR 0.95, 95\% CI 0.89-1.01) (table 6) for the westcoast fishermen. There was an increased incidence of lip cancer (SIR 1.92, 95\% CI 1.29-2.80), but squamous cell cancers of the skin or malignant melanomas were not increased (SIR 1.12, 95\% CI 0.88-1.43 and SIR 0.78, $95 \%$ CI $0.48-1.22$, respectively). There was no increased incidence of stomach cancer (SIR 0.92, 95\% CI $0.72-1.17$ ), and the incidence of esophagus cancer (SIR $0.39,95 \%$ CI $0.13-0.92$ ) was significantly decreased. In contrast to the results for the eastcoast fishermen, no significant decrease in colon cancers was seen (SIR 0.95, 95\% CI 0.76-1.19). As for the eastcoast fishermen, a suggestive but nonsignificant increase was seen for acute leukemias (SIR 1.86, 95\% CI 0.96-3.25). On the other hand, no increase in myelomas was observed. 
Table 5. Cancer incidence 1968-1988 among 2896 fishermen from the east coast.

\begin{tabular}{|c|c|c|c|c|}
\hline Cancer site ${ }^{a}$ & $\begin{array}{l}\text { Observed } \\
\text { cases } \\
\text { (N) }\end{array}$ & $\begin{array}{l}\text { Expected } \\
\text { cases } \\
\text { (N) }\end{array}$ & $\begin{array}{l}\text { Standardized } \\
\text { incidence } \\
\text { ratio }\end{array}$ & $\begin{array}{c}95 \% \\
\text { confidence } \\
\text { interval }\end{array}$ \\
\hline Lips (140) & 7 & 2.7 & 2.60 & $1.05-5.36$ \\
\hline Esophagus (150) & 0 & 2.1 & 0.00 & $0.00-1.78$ \\
\hline Stomach $(151)$ & 24 & 15.1 & 1.59 & $1.03-2.39$ \\
\hline Colon (153) & 5 & 13.4 & 0.37 & $0.12-0.87$ \\
\hline Rectum (154) & 9 & 10.5 & 0.86 & $0.39-1.63$ \\
\hline Liver, bile ducts (155) & 6 & 4.6 & 1.31 & $0.48-2.85$ \\
\hline Pancreas (157) & 4 & 6.6 & 0.61 & $0.16-1.55$ \\
\hline Lung (162) & 24 & 20.6 & 1.16 & $0.76-1.75$ \\
\hline Prostate (177) & 38 & 34.5 & 1.10 & $0.79-1.52$ \\
\hline Renal parenchyma (180.0) & 6 & 6.9 & 0.87 & $0.32-1.89$ \\
\hline Urinary bladder (181) & 10 & 13.7 & 0.73 & $0.35-1.34$ \\
\hline Melanoma (190) & 0 & 5.1 & 0.00 & $0.00-0.72$ \\
\hline Skin (191) & 22 & 9.6 & 2.28 & $1.45-3.50$ \\
\hline Brain (193) & 3 & 6.1 & 0.50 & $0.10-1.45$ \\
\hline Soft-tissue sarcoma (197) & 0 & 1.4 & 0.00 & $0.00-2.63$ \\
\hline Hodgkin's lymphoma (201) & 0 & 1.4 & 0.00 & $0.00-2.62$ \\
\hline Non-Hodgkin's Iymphoma $(200,202)$ & 5 & 5.8 & 0.85 & $0.28-1.99$ \\
\hline Multiple myeloma (203) & 6 & 2.9 & 2.08 & $0.76-4.53$ \\
\hline Lymphatic leukemia (204) & 4 & 3.2 & 1.23 & $0.34-3.15$ \\
\hline Myeloic leukemia (205) & 2 & 2.3 & 0.86 & $0.10-3.11$ \\
\hline Acute leukemia $(204.0,205.0,206.0,207.0)$ & 5 & 2.2 & 2.28 & $0.74-5.33$ \\
\hline All (140-209) & 197 & 193.5 & 1.02 & $0.88-1.17$ \\
\hline
\end{tabular}

a Code of the International Classification of Diseases (seventh revision) in parentheses.

Table 6. Cancer incidence 1965-1988 among 8477 fishermen from the west coast.

\begin{tabular}{|c|c|c|c|c|}
\hline Cancer site ${ }^{a}$ & $\begin{array}{c}\text { Observed } \\
\text { cases } \\
\text { (N) }\end{array}$ & $\begin{array}{c}\text { Expected } \\
\text { cases } \\
(\mathrm{N})\end{array}$ & $\begin{array}{l}\text { Standardized } \\
\text { incidence } \\
\text { ratio }\end{array}$ & $\begin{array}{c}95 \% \\
\text { confidence } \\
\text { interval }\end{array}$ \\
\hline Lips $(140)$ & 28 & 14.6 & 1.92 & $1.29-2.80$ \\
\hline Esophagus (150) & 5 & 12.7 & 0.39 & $0.13-0.92$ \\
\hline Stomach (151) & 71 & 77.2 & 0.92 & $0.72-1.17$ \\
\hline Colon (153) & 82 & 85.9 & 0.95 & $0.76-1.19$ \\
\hline Rectum (154) & 59 & 53.6 & 1.10 & $0.84-1.43$ \\
\hline Liver, bile ducts (155) & 24 & 24.6 & 0.97 & $0.63-1.47$ \\
\hline Pancreas (157) & 37 & 36.1 & 1.02 & $0.73-1.42$ \\
\hline Lung (162) & 73 & 80.6 & 0.91 & $0.71-1.14$ \\
\hline Prostate (177) & 224 & 231.7 & 0.97 & $0.85-1.10$ \\
\hline Renal parenchyma (180.0) & 28 & 30.6 & 0.91 & $0.62-1.34$ \\
\hline Urinary bladder (181) & 55 & 64.6 & 0.85 & $0.65-1.11$ \\
\hline Melanoma (190) & 20 & 25.8 & 0.78 & $0.48-1.22$ \\
\hline Skin (191) & 69 & 61.4 & 1.12 & $0.88-1.43$ \\
\hline Brain (193) & 24 & 26.1 & 0.92 & $0.60-1.38$ \\
\hline Soft-tissue sarcoma (197) & 3 & 6.4 & 0.47 & $0.10-1.37$ \\
\hline Hodgkin's lymphoma (201) & 9 & 5.6 & 1.61 & $0.74-3.05$ \\
\hline Non-Hodgkin's Iymphoma $(200,202)$ & 21 & 27.4 & 0.77 & $0.48-1.19$ \\
\hline Multiple myeloma (203) & 19 & 17.1 & 1.11 & $0.68-1.76$ \\
\hline Lymphatic leukemia (204) & 16 & 12.0 & 1.33 & $0.78-2.19$ \\
\hline Myeloic leukemia (205) & 6 & 12.0 & 0.50 & $0.18-1.09$ \\
\hline Acute leukemia $(204.0,205.0,206.0,207.0)$ & 12 & 6.4 & 1.86 & $0.96-3.25$ \\
\hline All $(140-209)$ & 979 & 1033.1 & 0.95 & $0.89-1.01$ \\
\hline
\end{tabular}

a Codes from the International Classification of Diseases (seventh revision) in parentheses.

\section{Direct comparisons between the cohorts}

When a direct comparison was made between the two fisherman cohorts, the eastcoast fishermen displayed a lower, though not statistically significant, mortality from ischemic heart disease (IRR 0.91, 95\% CI 0.77-1.09). Deaths from multiple myelomas were significantly in- creased among the eastcoast fishermen (IRR 3.22, 95\% CI 1.20-8.67).

The eastcoast fishermen had significantly elevated incidences of skin and stomach cancer (IRR 1.88, 95\% CI 1.15-3.09 and IRR 2.15, 95\% CI 1.32-3.50, respectively). For the incidence of multiple myelomas the 
IRR was 1.86 (95\% CI 0.71-4.88). A significantly decreased incidence in colon cancer was, on the other hand, observed among the eastcoast fishermen (IRR 0.35, 95\% CI $0.14-0.88$ ).

\section{Discussion}

\section{Cancer mortality and morbidity}

In accordance with the findings in an earlier study (5), significant risk excesses for squamous cell cancer of the lips were seen in both the west- and eastcoast cohorts. A strange finding was that the incidence of squamous cell cancer of the skin was elevated in the eastern, but not in the western cohort. This discrepancy remained when a direct comparison was made between the cohorts. A possible cause for these cancers is occupational exposure to oils and tar, and there is reason to believe that the eastcoast fishermen had a higher exposure to these compounds than the westcoast ones, as they worked more to preserve their smaller boats and nets. Another relevant factor is the relatively high exposure to ultraviolet light from outdoor work at sea. Sixteen of the 22 cases of skin cancer in the eastern cohort were diagnosed on the parts of the body (head and neck) most exposed to ultraviolet light (SIR 3.45, 95\% CI 2.02-5.70, comparisons with the general Swedish population). The standardized incidence ratio for the remaining body was 2.55 (95\% CI 0.94-5.56).

Exposure to damaging ultraviolet radiation, defined as the solar radiation weighted by the curve devised by the American Conference of Governmental Industrial Hygienists and the National Institute for Occupational Safety and Health is $10-15 \%$ higher along the southern part of the Baltic Sea, where many of the eastern fishermen had their fishing places, as compared with the west coast (7). However, this difference in exposure to damaging ultraviolet light is too small to explain the observed difference in the incidence of skin cancer. In addition, there was no difference in the incidence of lip cancer in relation to exposure to damaging ultraviolet light. It should be noted that the incidence of melanomas was not elevated in any of the cohorts. On the contrary, melanomas were significantly fewer than expected in the eastern cohort. This finding is in accordance with previous observations of a low incidence of malignant melanoma among outdoor workers with occupational exposure to ultraviolet light (8).

In discussions on the cause of skin cancer, it is noteworthy that fish contain high levels of arsenic and are the main source for the human uptake of this element (9). Two to $10 \%$ of the arsenic in fish is inorganic (10). Oral exposure to inorganic arsenic has been considered to increase the risk for squamous cell cancer of the skin through a tumor promotive effect (9). Whether the dietary intake of inorganic arsenic from fish involves such a risk is not known (10). There is, however, no reason to believe that the exposure to arsenic was higher in the eastcoast cohort. On the contrary, lean fish species like cod and plaice, which were preferably consumed by the westcoast fishermen, have higher arsenic levels than Baltic herring (11). Thus it is difficult to explain the observed difference in skin cancer incidence by this factor.

The difference between the cohorts in exposure to persistent organochlorine compounds may be a more relevant factor. The blood levels of dioxinlike organochlorine compounds, expressed as toxic equivalents, were two times higher among the eastcoast fishermen than among those from the west coast. In many species epithelial cells are the primary targets for the action of 2,3,7,8-tetrachlorodibenzo-p-dioxin (TCDD) and similar organochlorine compounds. Hyperplasia and attered differentiation in these cells, resulting in chloracne, are consistent findings after occupational or accidental exposure to TCDD $(12,13)$. Thus TCDD and similar compounds, which are also potent tumor promoters (14), could be discussed as contributors to the elevated number of skin cancers among the eastcoast fishermen. Another possibility is that, due to slightly different work habits, the eastcoast fishermen may have had more skin contact with tars and oils.

Mainly cancer mortality studies have been performed on subjects exposed to persistent organochlorine compounds. As the survival rate is very high for squamous cell skin cancer, mortality studies are unsuitable for exploring etiologic factors. An increased prevalence of skin cancers related to exposure to ultraviolet light (primarily due to an excess of basal cell carcinomas, which we did not study) has previously been reported among American Vietnam veterans with possible exposure to TCDD (15).

\section{Multiple myeloma, malignant lymphomas, soft-tissue} sarcoma

Excess mortality from myelomas was seen among the eastcoast fishermen, both in comparison with the regional reference population and in a direct comparison with the westcoast fishermen. In addition, the incidence of myelomas among the eastcoast fishermen was increased, though not significantly so. There were two cases of death from myeloma in the eastcoast cohort, and three in the westcoast cohort, that could not be retrieved as incident cases of myeloma in the cancer register. According to the scrutinized records, two of them should, however, have been registered in the cancer register, and for a third subject diagnosis of chronic lymphatic leukemia was registered instead. The accuracy of overall cancer diagnosis is far better in the Swedish Cancer Register 
than in the cause of death register, but for leukemias and myelomas there has previously been substantial underreporting to the cancer register (16). A suggestive increase in the incidence of multiple myelomas has been reported from the TCDD-exposed population in the Seveso area (17).

TCDD and similar compounds have, in some studies, been associated with an increase in risk for malignant lymphomas and soft-tissue sarcomas (18-20). None of these tumors were elevated in our cohorts.

\section{Stomach cancer}

The eastcoast fishermen had an increased incidence of stomach cancer. The same result did not appear for the westcoast fishermen. An elevated risk of stomach cancer in fishermen has previously been described in a Canadian proportional mortality study (21), and also among British fishermen (22). Dietary habits like high salt and smoked food intake have been associated with an increased incidence of stomach cancer (23). Nitrosamines, which can be found in smoked fish, are potent carcinogens. It was therefore noteworthy that the eastcoast fishermen consumed smoked fish twice as often as the westcoast fishermen (1). Smoked fish may also contain carcinogenic polycyclic aromatic hydrocarbons (24).

It has been proposed that nitroso compounds can also be formed endogenously in the stomach from dietary nitrates and secondary amines (25). However, exposure to methylamines (eg, dimethylamine, which could serve as a substrate for the formation of the potent carcinogen $\mathrm{N}$-nitrosodimetylamine) was higher among the westcoast fishermen than among the eastcoast fishermen (1).

A consistent finding in studies on diet and stomach cancer has been a negative association of stomach cancer with the intake of fresh fruits and vegetables. The fisherman cohorts did not, however, differ in that respect.

Suspected or verified occupational exposure to TCDD has been associated with stomach cancer in some studies $(26,27)$. However, these findings have not been confirmed in several more recent studies $(20,28,29)$.

\section{Colon cancer}

The eastcoast fishermen had a significantly decreased incidence of cancer of the colon. It is generally accepted that colon cancer risk is decreased by dietary fibers, and increased by high levels of dietary fat and protein, and a high total energy intake (30). The dietary interviews did not display any other difference than a higher intake of fatty fish among the eastcoast fishermen, as compared with the westcoast fishermen, which could explain the risk difference. An increase in risk has also been attributed to a low level of physical activity (31). The fishermen have, however, physically demanding work. Recent re- ports indicate that n-3 PUFA inhibit the development and growth of several experimental tumors, colon cancer being one $(32,33)$. So far, these findings have not been confirmed in humans, and whether a high intake of n-3 PUFA is related to the low colon cancer risk among the eastcoast fishermen is still very speculative.

\section{Mortality from cardiovascular diseases}

Mortality from cardiovascular diseases among Swedish employees should be expected to be lower than in the general population (34) because of an unfavorable pattern of risk factors (hypertension and smoking) among the unemployed (35). In addition, working as a fisherman is associated with heavy physical exercise, and persons with symptoms of ischemic heart disease may be withdrawn from the active work force. This potential bias, introduced by incomparability between the eastern fishermen and the reference group, is, however, not fully applicable in our study. First, it should be noted that the eastcoast fishermen smoked more than both the westcoast fishermen and the reference groups (1), and consequently smoking cannot have confounded our findings. Second, an increased mortality from ischemic heart disease has previously been described for British deep sea fishermen (22), and this finding speaks against "healthy worker selection" with regard to ischemic heart disease. Third, the inclusion criterion for the cohorts was at least one year of membership in the fishermen's organization, which is not incompatible with an early withdrawal from work. Even after retirement, there is reason to believe that dietary habits do not change as regards fish consumption. Fourth, many of the fishermen were not employees, but were self-employed instead.

A high consumption of fish has, in several epidemiologic studies, been associated with a low risk for cardiovascular diseases. Inuits from Greenland, who have a high intake of marine food, have also low mortality from ischemic heart disease (36). In studies from Japan, Sweden, and The Netherlands there was an inverse relation between fish consumption and death from ischemic heart disease $(4,37,38)$. These findings were, however, not confirmed in studies from Hawaii and Norway (39--41).

The beneficial effects on cardiovascular mortality from fish consumption have been attributed to n-3 PUFA, mainly found in fatty fish species (33). The fishermen from the east coast had both a decreased risk for death from ischemic heart disease and a substantially higher intake of fatty fish than their western colleagues and the referents. We have previously found a correlation between the intake of fatty fish and the serum levels of n-3 PUFA (42).

In some epidemiologic studies (43-49), but not in all $(50,51)$, low levels of selenium in blood have been associated with an increased risk for ischemic heart dis- 
ease. Fish consumption is important in Sweden for the dietary intake of selenium (52), which was reflected by a $10-15 \%$ increase of plasma selenium in Swedish fishermen as compared with referents from the general population (1). As the plasma selenium levels of the eastcoast fishermen did not differ from those of the westcoast fishermen, the selenium status is, however, an unlikely explanation for the difference in ischemic heart disease between the cohorts.

Hereditary factors, as reflected by, for example, high plasma levels of lipoprotein (a), may affect the risk for ischemic heart disease (53), but as there was no difference between the fishermen from the different coastal areas in this respect (1), at least this genetic factor has not affected the study outcome.

High dietary levels of n-3 PUFA have been suggested as a possible protection against atherosclerotic cardiovascular disease by reducing thrombocyte aggregation and increasing bleeding time $(54,55)$ or by reducing the plasma levels of total cholesterol and triglycerides (56, 57). Among high consumers of fatty fish from the Baltic sea, decreased levels of plasma triglycerides and increased levels of high-density lipoprotein cholesterol in plasma were found (42).

It has been suggested that reduced platelet aggregation due to a high dietary intake of n-3 PUFA might well protect against coronary thrombosis but at the same time involve a greater bleeding tendency and thus increase the risk for hemorrhagic stroke, as indicated from studies of Inuits $(36,58)$. In the previous study on fishermen from the Baltic Sea (5), there was a nonsignificant increase in mortality from cerebrovascular disease. This finding was not confirmed in our present study.

\section{Violent deaths}

Earlier studies on fishermen have displayed an increased mortality from water accidents and drowning $(5,22,59)$. Our findings were similar in that deaths from drowning were elevated, especially in the eastern cohort.

\section{Concluding remarks}

Consumption of fatty fish from the Baltic Sea causes exposure to toxic, persistent organochlorine compounds. High consumers of such fish displayed an increased risk for stomach and skin cancer. These findings cannot, however, with any certainty be attributed to the exposure to organochlorine compounds, as the high consumers were also exposed to other potentially carcinogenic substances (arsenic, compounds in smoked fish).

When the total health effects from the consumption of fatty fish from the Baltic Sea are evaluated, it is noteworthy that a suggestive decrease in mortality from ischemic heart disease was noted among high consumers.
According to our results, no dietary restrictions for fatty fish from the Baltic Sea can be justified for men. As there, however, was an increasing concern for a possible association between exposure to persistent organochlorine compounds and breast cancer in women $(60,61)$, the cancer incidence among the fishermen's wives should also be evaluated. Moreover, as there is also a possible association between PCB exposure through fish and reproductive outcome $(62-64)$, it should be assessed before dietary recommendations for women can be made.

\section{Acknowledgments}

This work was supported by grants from the Swedish Environmental Protection Agency, the Swedish Work Environment Fund, the Swedish Cancer Society, Gunnar, Arvid and Elisabeth Nilsson's Fund for research on cancer, and the Medical Faculty, Lund University. We thank Ms C Andersson, Ms K Anderson-Lindén, and Ms $\mathrm{M}$ Wikman for their help with establishing the cohort.

\section{References}

1. Svensson B-G, Nilsson A, Jonsson E, Schütz A, Åkesson B, Hagmar L. Fish consumption and exposure to persistent organochlorine compounds, mercury, selenium and methylamines in Swedish fishermen. Scand J Work Environ Health. 1995;21: 96-105.

2. Asplund L, Jansson B, de Wit C, Bergek S, Hjelt M, Rappe C, et al. Polychlorinated dibenzo-p-dioxins (PCDD) and dibenzofurans (PCDF) compared to other organohalogen pollutants in biological samples from Swedish ecosystems. In: Hutzinger O, Fiedler H, editors. Dioxin'90, vol 1. Bayreuth: Eco-Informa Press, 1990:405-8.

3. Rappe C, Bergqvist PA, Kjeller LO. Levels, trends and patterns of PCDDs and PCDFs in Scandinavian environmental samples. Chemosphere 1989;18:651-8.

4. Kromhout D, Bosschieter EB, De Lezenne Coulander C. The inverse relation between fish consumption and 20-year mortality from coronary heart disease. N Engl J Med 1985;312: $1205-9$.

5. Hagmar L, Lindén K, Nilsson A, Norrving, B, Åkesson B, Schütz $A$, et al. Cancer incidence and mortality among Swedish Baltic Sea fishermen. Scand J Work Environ Health 1992; $18: 217-24$.

6. Checkoway H, Pearce NE, Crawford-Brown DJ. Research methods in occupational epidemiology. Oxford: Oxford University Press, 1989.

7. Josefsson W. Solar ultraviolet radiation in Sweden. Norrköping: Sveriges Meteorologiska och Hydrologiska Institut (SMHI), 1986. SMHI Reports Meteorology and Climatology.

8. International Agency for Research on Cancer (IARC). Solar and ultraviolet radiation. Lyon: IARC, 1992. IARC monographs on the evaluation of the carcinogenic risk of chemicals to humans, vol 55.

9. World Health Organization (WHO). International program on 
chemical safety: arsenic. Geneva: WHO, 1981. Environmental health criteria, no 18.

10. Joint Group of Experts on the Scientific Aspects of Marine Pollution (GESAMP). Review of potentially harmful substances - arsenic, mercury and selenium. Geneva: WHO, 1986. WHO report studies no 28.

11. Oskarsson A. Arsenic. In: Slorach S, Adams B, editors. Nordic expert meeting: fish as food. Copenhagen: Nordic Council of Ministers, 1992:89-93. Nordiske seminar- och arbejdsrapporter 1992:568.

12. Suskind RR. Chloracne, "the hallmark of dioxin intoxication." Scand J Work Environ Health 1985;11:165-71.

13. Silbergeld EK, Gasiewicz TA. Dioxins and the Ah receptor. Am J Ind Med 1989;16:455-74.

14. Flodström S, Ahlborg G. Relative liver tumor promoting activity of some polychlorinated dibenzo-p-dioxin-, dibenzofuran- and biphenyl-congeners in female rats. Chemosphere 1992;25:169-72

15. Wolfe W, Michalek J, Miner J, Rahe A, Silva J, Thomas W, et al. Health status of air force veterans occupationally exposed to herbicides in Vietnam: I. physical health. JAMA 1990;264: $1824-31$

16. Mattson B, Wallgren A. Completeness of the Swedish Cancer Register: non-notified cancer cases recorded on death certificates in 1978. Acta Radiol Oncol 1984;23:305-13.

17. Bertazzi PA, Pesatori A, Consonni D, Tironi A, Landi MT, Zocchetti C. Cancer incidence in a population accidentally exposed to 2,3,7,8-tetrachlorodibenzo-para-dioxin. Epidemiology 1993;4:398-406

18. Hardell L, Eriksson M, Lenner P, Lundgren E. Malignant lymphoma and exposure to chemicals, especially organic solvents, chlorophenols and phenoxy acids: a case-control study. Br J Cancer 1981;43:169-76.

19. Hardell L, Eriksson M. The association between soft tissue sarcomas and exposure to phenoxiacetic acids: a new case referent study. Cancer 1988;62:652-6.

20. Fingerhut MA, Halperin WE, Marlow DA, Piacitelli L, Honchar P, Sweeney M, et al. Cancer mortality in workers exposed to 2,3,7,8-tetrachlorodibenzo-p-dioxin. New Engl J Med $1991 ; 224: 212-8$.

21. Gallagher R, Threlfall W, Band P, Spinelli J. Cancer mortality experience of woodworkers, loggers, fishermen, farmers, and miners in British Columbia. Natl Cancer Inst Monogr 1985;69: $163-7$.

22. Schilling R. Hazards of deep-sea fishing. Br J Ind Med 1971; 28:27-35.

23. Howson CP, Hiyama T, Wynder EL. The decline in gastric cancer: epidemiology of an unplanned triumph. Epidemiol Rev 1986;8:1-27.

24. Alexander J, Becher G, Dybing E. Polycyclic aromatic hydrocarbons (PAH) in fish. In: Nordic expert meeting: fish as food. Copenhagen: Nordic Council of Ministers, 1992:181-94. Nordiske seminar- och arbejdsrapporter 1992:568.

25. Correa P, Haenzel W, Cuello C, Archer M, Tannenbaum S. A model for gastric cancer epidemiology. Lancet 1975;2:5860.

26. Axelson O, Sundell L, Andersson K, Edling C, Hogstedt C, Kling $\mathrm{H}$. Herbicide exposure and tumor mortality: an updated epidemiologic investigation on Swedish railroad workers. Scand J Work Environ Health 1980;6:73-9.

27. Thiess AM, Frentzel-Beyme R, Link R. Mortality study of persons exposed to dioxin in a trichlorophenol-process accident that occured in the BASF AG on November 17th, 1953. Am J Ind Med 1982;3:179_-89.
28. Manz A, Berger J, Dwyer J H, Flesch-Janys D, Nagel S, Waltsgott $\mathrm{H}$. Cancer mortality among workers in chemical plant contaminated with dioxin. Lancet 1991;338:959-64.

29. Saracci R, Kogevinas M, Bertazzi P A, Bueno de Mesquita BH, Coggon D, Green LM, et al. Cancer mortality in workers exposed to chlorophenoxy herbicides and chlorophenols. Lancet 1991;338:1027-32.

30. Potter JD. Large bowel cancer: epidemiology and biology. Z Gastroenterol 1989;24:137-40.

31. Gerhardsson M, Floderus B, Norell SE. Physical activity and colon cancer risk. Int J Epidemiol 1988;17:743-6.

32. Karmali RA. n-3 fatty acids and cancer. J Int Med 1989;225 suppl 1:197-200.

33. Simopoulus AP. Omega-3 fatty acids in health and diseas and in growth and development. Am J Clin Nutr 1991;54:43863.

34. Gustavsson P. Cancer and ischemic heart disease in occupational groups exposed to combustion products. Stockholm: Arbetarskyddsverket, 1989. Arbete och hälsa, no 21.

35. Diderichsen F, Lindberg G. Better health — but not for all: the Swedish public health report, 1987. Int J Health Serv 1989; $19: 221-55$

36. Kronmann N, Green A. Epidemiological studies in the Upernavik district, Greenland: incidence of some chronic diseases 1950-74. Acta Med Scand 1980;208:401-6.

37. Norell SE, Ahlbom A, Feychting M, Pedersen NL. Fish consumption and mortality from coronary heart disease. $\mathrm{Br}$ Med J 1986:293:426

38. Hirai A, Terano T, Tamura Y, Yoshida S: Eicosapenatenoic acid and adult diseases in Japan: epidemiological and clinical aspects. J Intern Med 1989;225 suppl 1:69-75.

39. Curb JD, Reed JD. Fish consumption and mortality from coronary heart disease [letter]. N Engl J Med 1985;313:821.

40. Vollset SE, Heuch I, Bjelke E. Fish consumption and mortality from coronary heart disase [letter]. N Engl J Med 1985; 313:820-1.

41. Simonsen T, Vårtun $\AA$, Lyngmo V, Nordøy A. Coronary heart disease, serum lipids, platelets and dietary fish in two communities in northern Norway. Acta Med Scand 1987;222:23745.

42. Svensson B-G, Åkesson B, Nilsson A, Skerfving S. Fatty acid composition of serum phosphatidylcholine in healthy subjects consuming varying amounts of fish. Eur J Clin Nutr 1993;47: $132-40$.

43. Salonen JT, Alfthan G, Huttunen JK, Pikkarainen J, Puska P. Association between cardiovascular death and myocardial infarction and serum selenium in a matched-pair longitudinal study. Lancet 1982;2:175-9.

44. Salonen JT, Salonen R, Pentillae I, Herranen J, Jauhiainen M, Kantola $M$ et al. Serum fatty acids, apolipoproteins, selenium and vitamin antioxidants, and the risk of death from coronary heart diseadse. Am J Cardiol 1985;56:226-31.

45. Salonen JT. Selenium in ischemic heart disease. Int J Epidemiol 1987;16 suppl: 323-8.

46. Virtamo J, Valkeila E, Alfthan G, Pusar S, Huttunen JK, Karvonen MJ. Serum selenium and the risk of coronary heart disease and stroke. Am J Epidemiol 1985;122:276-82.

47. Beaglehole R, Jackson R, Watkinson J, Scragg R, Yee RL. Decreased blood selenium and risk of myocardial infarction. Int J Epidemiol 1990;19:918-22.

48. Kok FJ, Hofman A, Witteman JCM, de Bruijn AM, Kruyssen DHCM, de Bruin M, et al. Decreased selenium levels in acute myocardial infarction. JAMA 1989;261:1161-4.

49. Suadicani P, Hein HO, Gyntelberg F. Serum selenium concen- 
tration and risk of ischaemic heart disease in a prospective cohort study of 3000 males. Atherosclerosis 1992;96:33-42.

50. Ringstad J, Jacobsen BK, Thomassen Y, Thelle DS. The Tromsø heart study: serum selenium and risk of myocardial infarction a nested case-control study. J Epidemiol Community Health 1987:41:329-32.

51. Miettinen TA, Alfthan G, Huttunen JK, Pikarainen J, Naukkarainen V, Mattila $S$, et al. Serum selenium concentrations related to myocardial infarction and fatty acid content of serum lipids. Br Med J 1983;287:517—9

52. Svensson B-G, Schïtz A, Nilsson A, Åkesson I, Åkesson B, Skerfving S. Fish as a source of exposure to mercury and selenium. Sci Total Environ 1992;126:61-74.

53. Scanu A, Lawn R, Berg K. Lipoprotein(a) and atherosclerosis. Ann Intern Med 1991;115:209-18.

54. Dyerberg J, Bang HO, Stoffersen E, Moncada S, Vane JR. Eicosapentaenoic acid and prevention of thrombosis and atherosclerosis. Lancet 1978;2:117—9.

55. Thorngren M, Gustafson A. Effects of 11-week increase in dietary eicosapentaenoic acid on bleeding time, lipids, and platelet aggregation. Lancet 1981;2:1190-3.

56. Bang HO, Dyerberg J. Plasma lipids and lipoproteins in Greenlandic west coast Eskimos. Acta Med Scand 1972;192:8594.

57. Harris WS, Connor WE, McMurray MP. The comparative reduction of the plasma lipids and lipoproteins by dietary polyunsatuarated fats: salmon oil versus vegetable oil. Metab- olism 1983;32:179-84.

58. Bjerregaard P, Gehlert Johansen L. Mortality patterns in Greenland: an analysis of potential years of life lost 196883. Arctic Med Res 1987;46:71-7.

59. Neutel CI. Mortality in fishermen: an unusual age distribution. Br J Ind Med 1990;47:528_-32.

60. Falck F, Ricci A, Wolff MS, Godbold J, Deckers P. Pesticides and polychlorinated biphenyl residues in human breast lipids and their relation to breast cancer. Arch Environ Health 1992; 47:143-6

61. Wolff MS, Toniolo PG, Lee EW, Rivera M, Dubin N. Blood levels of organochlorine residues and risk of breast cancer. JNCI 1993;85:648—52.

62. Jacobson JL, Fein GG, Jacobson SW, Schwartz PM, Dowler JK. The transfer of polychlorinated biphenyls (PCBs) and polybrominated biphenyls (PBBs) across the human placenta and into maternal milk. Am J Publ Health 1984;74:378-9.

63. Jacobson JL, Jacobson SW, Humphrey HEB. Effects of in utero exposure to polychlorinated biphenyls and related contaminants on cognitive functioning in young children. $\mathrm{J} \mathrm{Pe}$ diatr 1990;116:38 - 45

64. Jacobson JL, Jacobson SW, Humphrey HEB. Effects of exposure to PCBs and related compounds on growth and activity in children. Neurotoxicol Teratol 1990;12:319-26.

Received for publication: 25 March 1994 